\title{
Mediations and Imaginaries on Climate Change and Global Warming Among Peasants in Mexico City
}

\author{
Bañuelos, J., Meneses, M. \\ Tecnológico de Monterrey-Mexico City Campus, Mexico
}

\begin{abstract}
This study explores the symbolic imaginary and forms of mediation on climate change and global warming, with the peasants of San Gregorio, Xochimilco, an agricultural area that survives in one of the largest in the world conurbations, Mexico City. We used a mixed method. Through a representative, observation and interview with our study subjects explored survey semantic-imaginary symbolic associations that farmers in the community have on both phenomena. We found that both are non-functional at the time when farmers describe the problems they experience the effects and possible solutions to climate variations. We believe that it is essential to explore the language used affected communities when proposing public policies, non-governmental actions and scientific research related to climate variations in local environments as studied here.
\end{abstract}

Keywords: climate change, global warming, symbolic imaginary, perceptions, media consumption

\section{Introduction}

The objective of this study is to explore the symbolic imaginary and media consumption around the basic concepts of climate change and global warming amongst the chinamperos community in the village of San Gregorio, Xochimilco, Mexico.

The term chinamperos refers to farmers who work in the chinampas, a cultivation technique begun by the Toltecs in the sixteenth century. The word derives from the word chinamitl of the Náhuatl language, meaning "near the reeds". A chinampa is a short extension of land in the lakes neighboring Mexico City, where flowers and vegetables are grown (DRAE, 2015). Throughout this article, we refer to the term in the original Spanish. There is no direct translation, and the word refers to the local and historic cultivation methods that are the subject of this study.

During the month of September 2014, we conducted a field study using a questionnaire administered to 75 farmers who work directly in the chinampas of San Gregorio. The questionnaire was complemented by informal interviews with farmers of different ages, which gave us more insight into the semantic associations that are made about climate change and global warming, as well as the symbolic imaginary around both.

The study explores the farmers' perceptions around the causes and consequences of climate change in Mexico; in particular, in the local context of agricultural activities. We adapt the concepts of perception used by Glynn et al. (1999) and the terms "fuzzy/general" and "timely/particular" to distinguish these perceptions.

Bañuelos, J., Ph.D., Professor, Department of Communication and Digital Art, Tecnológico de Monterrey-Mexico City Campus.

Meneses, M., Ph.D., Professor, EscuelaNacional de Educación y Humanidades, Tecnológico de Monterrey-Mexico City Campus. 
The study also yields new information about the notions that farmers have about governmental support and actions taken by governmental authorities on climate change in their community, as well as the causes, solutions and resilience measures that they consider most important in addressing the impact of climate change on their communities.

We believe that our findings may provide tools to better understand the phenomena of climate change and global warming in a semi-rural community of an emerging economy in order to implement or improve community action, to articulate public policies and media campaigns (given the preeminent role media plays in the symbolic construction of the phenomena), and to design new technological responses. This study seeks to contribute to the adaptation of rural communities in the face of the global warming and climate change as it affects sustainable development and community life.

The study is based on three fundamental questions that serve as a research guide:

- What are the fuzzy/general and timely/particular perceptions that the chinamperos of San Gregorio have about climate change and global warming?

- What are the symbolic imaginaries (or semantic associations, for the purposes of this study) around climate change within the chinamperos community of San Gregorio, Xochimilco?

- What characterizes the media consumption by chinamperos on climate change and global warming?

\section{San Gregorio, Xochimilco, Mexico}

The village of San Gregorio, Atlapulco in Xochimilco consists of 117 blocks and a total population of almost 20,000 inhabitants. Of the 117 blocks, a total of 93 maintain a level of marginalization labeled as "high" to "very high", which makes this area of Mexico City a focus for social concern and attention. The total population of the village is around 20,000 people, of which 7,351 are considered to be the economically active population (INEGI, 2010).

The community of chinamperos of San Gregorio, Xochimilco, Mexico, form part of a semi-rural population that have experienced notable changes in terms of weather, urban population growth, and in respect to their agricultural and economic activities. This is predominately due to the community's proximity to Mexico City, a mega-urban agglomeration comprised of more than eight and a half million inhabitants and about 20 million people in the metropolitan area. The city boundaries include 60 surrounding municipalities.

San Gregorio is traditionally an agricultural town where vegetable farming still predominates via the system of chinampas that are a part of Xochimilco's historic system of water channels. This community is a paradigmatic site for the study of climate change and global warming. The closeness of San Gregorio to Mexico City has exposed the community to economic, political, social, cultural and environmental changes as a result of the excessive growth of the mega-city. The community has been forced to share the urban problems that include water supply, food access, transportation, housing and employment. The now semi-rural town has also faced exposure to outsourcing, pollution, increased product consumption, socioeconomic inequalities, and the impact on the environment in its geographical area.

\section{Mediated Perception and the Construction of Symbolic Imaginaries}

To imagine is not a minor social practice but rather a social act in mediated societies that provokes resistance, irony, selectivity and agency (Appadurai, 2001). As we saw in San Gregorio, beginning with representations by the media, the imagination is the process through which the population constructs a symbolic 
imaginary that can lead to an action or to claiming agency that can then lead to forming consciousness. In order to better understand this process, we distributed a questionnaire ${ }^{1}$, and completed informal interviews in situ with members of three different generations (grandparents-parents-children/young adults) of chinamperos. These qualitative and quantitative measures allow us to explain the social construction of meaningfulness around ideas of climate change in a community visibly affected by it.

Table 1

General Characteristics of San Gregorio, Atlapulco

\begin{tabular}{|c|c|c|c|c|c|}
\hline \multirow{2}{*}{ Sociodemographics } & \multirow{2}{*}{ Total } & \multicolumn{4}{|c|}{ Degree of marginalization } \\
\hline & & Very high & High & Average & $\mathrm{N} / \mathrm{A}$ \\
\hline Blocks & 117 & 44 & 49 & 20 & 4 \\
\hline Total population & 19,265 & 8,089 & 8,281 & 2,785 & \\
\hline Men & 9,382 & 4,008 & 4,018 & 1,311 & 45 \\
\hline Women & 9,877 & 4,081 & 4,263 & 1,474 & 69 \\
\hline \multicolumn{6}{|l|}{ Employment } \\
\hline Economically active population & 7,351 & 3,021 & 3,232 & 1,061 & 37 \\
\hline Economically inactive population & 6,790 & 2,751 & 2,915 & 1,089 & 35 \\
\hline Occupied population & 7,295 & 2,996 & 3,209 & 1,053 & 37 \\
\hline O.P. Secondary sector & 785 & 406 & 291 & 81 & 7 \\
\hline O.P. Tertiary sector & 5,132 & 2,026 & 2,289 & 791 & 26 \\
\hline O.P. As employee or skilled laborer & 4,310 & 1,738 & 1,889 & 662 & 21 \\
\hline O.P. As day laborer or unskilled laborer & 384 & 213 & 149 & 20 & 2 \\
\hline \multicolumn{6}{|l|}{ Housing } \\
\hline Inhabited houses total & 4,151 & 1,741 & 1,795 & 591 & 24 \\
\hline Houses partially inhabited & 4,037 & 1,694 & 1,747 & 574 & 22 \\
\hline Houses with drainage system & 2,769 & 920 & 1,326 & 523 & \\
\hline Houses with internal plumbing & 1,679 & 394 & 816 & 469 & \\
\hline Houses with plumbing on land & 2,000 & 1,021 & 886 & 93 & \\
\hline \multicolumn{6}{|l|}{ Homes } \\
\hline Total homes & 4,200 & 1,756 & 1,830 & 592 & 22 \\
\hline Population in homes & 18,837 & 7,927 & 8,089 & 2,717 & 104 \\
\hline \multicolumn{6}{|l|}{ Neighborhoods } \\
\hline \multicolumn{6}{|l|}{ Pueblo de Santa Cruz Acapixca } \\
\hline \multicolumn{6}{|l|}{ San Juan Minas } \\
\hline \multicolumn{6}{|l|}{ San Juan Moyotepec } \\
\hline \multicolumn{6}{|l|}{ San Andres } \\
\hline Los Reyes & & & & & \\
\hline
\end{tabular}

Note. Source:Original research based on Population and Housing Census, INEGI 2010.

The concept of mediation is useful as a model that seeks to account for the forms/institutions that communication takes on in various social formats, as well as the logics that govern the modes of communication and meaning-making between available resources, organization of labor, political orientations of the media, and finally, the social uses of communication products (Barbero, 2003).

On our visits, via interviews and the questionnaire, we explored the types of media consumption that our study subjects used to learn about the research topic. We understand media consumption to mean "all the

1 The questionnaire was applied by Norlatina (2014). 
processes of appropriation and use of the products in which the symbolic value overrides the values of use and exchange" (Garcia, 2006, p. 89). As noted by Garcia Canclini, cultural consumption from a socio-anthropological perspective does not only include the arts, but also products conditioned by commercial interests such as mass media productions.

\section{Fuzzy and Timely Perceptions}

Perceptions form part of public opinion, wherein public opinion is understood as a complex process that operates on two levels: on the one hand, the social influence exerted by family, school, church, and the expression of various social groups, etc.; and, on the other hand, the influence of the media. These two factors interact and contribute to generate a certain perception of events that have occurred in the immediate environment of individuals (Glynn et al, 1999).

While both levels are important in shaping perceptions, mass media is especially significant in so far as media communications evoke the issues upon which a society should prioritize attention and reflection. In this sense, media communications hold a transcendental importance in shaping attitudes (Oskamp \& Shulz, 1991).

Attitude refers to positive or negative feelings towards an object. Attitudes consist of cognition (beliefs), emotion (or feelings), and behavior. When an attitude is expressed, either verbally or through behavior, it is called an opinion (Oskamp \& Shulz, 1991; Glynn et al., 1999).

When public opinion is explored in a field study through opinion polls - in our case, when we examine the perceptions of the target population (chinamperos) about changes in the natural environment - this is done on two levels: a general level, called "fuzzy perception" because of the spontaneous and open answers of respondents to a question that is also open and very general, and a specific level, or "timely perception" in which the questions are specific, delimited by timing, and focus on the characteristics of certain phenomena.

In our case study, the general questions (fuzzy perception) took the form of direct questions and semantic associations regarding complex terms like global warming and climate change, while specific questions (timely perception) articulated a local contextualization of the terms. These more specific questions asked respondents to translate the general terms of study into their own particular words. We focused on an exploration of the causes, consequences and, if possible, the adaptability of the chinamperos to changes in the environment, as well as possible mechanisms for control that they could identify.

In this project, the following dimensions were addressed:

- Fuzzy perception and semantic association around the concept of "global warming";

- Fuzzy perception and semantic association around the concept of "climate change";

- Mediated perception and the construction of symbolic imaginary through media consumption.

\section{Methodology}

\section{Climate Change: Symbolic Imaginaries, Mediations, and Media Consumption}

Our methodology is based the study of five key concepts: climate change, global warming, symbolic imaginaries, mediations and media consumption. These concepts form the theoretical basis of this research, and together they form the framework of our exploration in the community of San Gregorio chinamperos.

In this study, we investigate the social imaginary of our study subjects because we understand this range of signifiers to give meaning to reality, as well as to the social construction around the phenomena. Here, the "social" represents the path of human collective life. It is an archeology of knowledge in words, expressed 
through representation and rebuilding diverse imaginaries, through the application of technologies, and through the use of all media forms from analog to digital (all replete with information) (Garcia, 2009).

For Castoriadis (1983), institutions such as language, family, modes of production and the significations that these institutions embody bring cohesion to a society. This set of meanings is called the "social imaginary". It constitutes a shifting sense of symbolic order without which a society can hardly define itself and find its place in the world.

Following Castoriadis (1984), a social imaginary is a historical construction that covers all institutions, norms and symbols shared by a particular social group, and that despite its imagined character, operates in reality. It offers both opportunities and constraints for the actions of the subjects. Thus, an imaginary is not a fiction or a lie; rather, it is a reality that has practical consequences for people's daily lives (Castoriadis, 1984, p. 199; Moreno \& Rovira, 2009).

According to Pintos (2004, cited in Aliaga, Basurto, \& Cabrera, 2013), a function of the social imaginary may be to provide "global explanations of fragmented phenomena" to give an overview of different lived experiences or individual perspectives around a particular topic. As such, the social imaginary is part of a symbolic network that is dynamic, convergent and historical. It "establishes an array of connections between different elements of the experience of individuals and networks of ideas, images, feelings, wants and projects that are available in a culturally-determined area" (Pintos, 1995, p. 5, quoted in Aliaga et al., 2013).

The social imaginary is a tool to go beyond appearances and the mere identification of discursive elements. It provides a schematic picture of group communication that relates to the myths, beliefs, archetypes, daydreams, and the deeper subjectivities of its subjects. This is its value (Pintos, 1995, cited in Aliaga et al., 2013).

Social imaginary, from Pintos's systematic perspective (2004), can be understood as "collective representations that govern systems of identification and social integration, and make visible social invisibility". They are "(1) socially-constructed, schemes, (2) that allow us to perceive, explain and intervene, (3) that which each differentiated social system, (4) constructs as reality". "Imaginaries are abstract constructs that operate in their own medium appropriate to each differentiated system, and where communication naturalizes the construction of reality" (Pintos, J., 2004, p. 20, cited in Aliaga et al., 2013).

The social imagination not only permeates the behavior of individual human beings, but also saturates companies and their brands, institutions, media discourse, political actors, mass communication, and historical and environmental events (García \& Millan, 2008, p. 3).

In so far as media discourse forms part of the social imaginary, it builds and nourishes it. As noted by Plaza (2009), the selection of texts produced and disseminated by the media function as elements of analysis because these texts serve to study the social order as symbolic order. The media have the great capacity to build discourses that have widespread dissemination and legitimacy, and therefore can influence the construction and reproduction of the dominant social imaginary.

The theory of social imaginary has also been studied in relation to climate change. The imaginaries around climate change have been studied as aesthetic, risky, illusory and ideological constructs (Luke, 2014). For Yusoff and Garbys (2011), imaginative practices play an important role in scientific practice and scenario-building.

Authors such as Levy \& Spicer (2013) construct the concept of climate imaginaries that share socio-semiotic systems, which structure the field of comprehension around climate change. In turn, Leff (2010) 
wonders whether the social imaginaries of culturally situated identities might mobilize new social actors and inspire "environmental democracy".

For example, the discursive production generated in situ in the farming community sample of this study refers to various socio-imaginary levels, providing a textual portrait of a particular part of their reality (Murillo \& Mena, 2006, p. 32).

From a methodological standpoint for social research, the social imagination provides a significant substrate, or a conceptual map, based on meanings that support larger discourses, such as the social extra-group level, or the society as a whole (universe). The group represents this larger discourse via the conjunction between the imaginary and the lived (Murillo \& Mena, 2006, p. 32, cited in Aliaga et al., 2013).

Following Murillo and Mena, "we are interested in both the speeches and the actions of subjects, because through them we collect representations that evoke distinct social phenomena when they are translated into concrete practices: group, institutional, and cultural" (Murillo \& Mena, 2006, p. 32, cited in Aliaga et al., 2013).

From the point of view of field research, the most common tools for such studies are focus groups or samples at the organization level. As in the case of the farmers of San Gregorio, this allows, as Baeza points out, the detection of overt or latent conflict. Such conflict exposes misunderstandings or miscommunications based on imaginaries created by lack of information, limited information, or distorted communication between the various levels of an organization. This is a natural result of the nature of "social imaginaries that are constructed through the potential communicability of human experience", wherein communicability is not complete, but fragmentary. "It is transmitted or communicable ingeneral terms, not in the minuteness of detail" (Baeza, 2003, p. 22, cited in Aliaga et al., 2013).

Climate change and global warming are two operational concepts that now serve as fundamental and central aspects of scientific, media, and political discourses. The two terms refer to the problematic of risk assessment, supportive action, preventive measures, public policies, national development plans and media information as focused on weather changes and their impact on the environment.

In 2005, the Intergovernmental Panel on Climate Change (IPCC) of the United Nations established a glossary of terms on climate change and global warming that is used by Mexican and international institutions and government bodies in their programs and public policies. This glossary serves as a controlled set of terms in order to trace the basic concepts under study.

We understand climate change to mean the alteration over time of the factors that characterize a climate as a result of natural phenomena or human action (Semarnat, 2009). It is important to note that although the definition covers both natural changes in a climate system and temperature variations caused by various human activities, local and global climate action programs generally focus on reducing or mitigating the factors of anthropogenic causes.

In our working visits to San Gregorio, it was clear that the concept of climate change is not familiar to the elderly population, although they had heard of global warming. The IPCC defines global warming (global warming or atmospheric warming) as the gradual increase, observed or projected, in global surface temperature, as one of the consequences of radioactive forcing caused by anthropogenic emissions (IPCC, 2015). According to the UNFCCC, it is a change attributed directly or indirectly to human activity that alters the composition of the global atmosphere in addition to natural climate variability observed over comparable time periods (IPCC, Climate 2015). 
Social imaginaries are an inescapable fact in societies with mass media forms that provoke resistence, irony, selectivity, and agency (Appadurai, 2001). We set out to investigate the imaginaries around these phenomena in San Gregorio, so as to better understand the range of signifiers that are used to articulate meaningfulness within their particular context.

\section{Framework and Sample Size}

Our sample framework consists of three databases of the National Institute of Statistics, Geography and Informatics (INEGI) as associated with the last Census on Population and Housing in 2010: (1) Main results of the census for basic geo-statistical (census tracts) areas and urban blocks; (2) Main results by locality (ITER); and (3) census mapping.

Because there is no available information on the distribution of farmers' homes nor on housing patterns, we decided to identify a sample fraction based on the information reported by INEGI, amounting to $19.5 \%$ of total laborers or farmers reported by the Census on Population and Housing by INEGI in 2010. By calculating a probability proportional to size (PPS), we estimated the total fraction for our sample to be 75 cases.

The results presented are not simple frequencies, but estimates based on the use of growth factors, calculated as the inverse of the selection probability of each individual in the sample. We received two rejections to be interviewed that were then replaced by interviews with other chinamperos working in the same area. Although each percentage has an associated margin of error, the design of our sample guarantees that in general estimates at least 95 out of 100 times, the margin of error does not exceed $\pm 5.0 \%$. In public opinion studies, possibilities of error (even beyond sample errors) must be considered also, such as those caused by the phrasing of questions and the impact of working in the field. The information obtained reflects the perceptions of a sample of 75 chinamperos, of which $39.2 \%$ are landowners and $60.8 \%$ are employed farmers. In the following tables, results are reported for both sectors, since the questionnaire was distributed separately to each group. The differentiation allows for a comparison of similarities and differences between landowners and employed farmers.

\section{Results}

\section{Fuzzy Perceptions of Changes in the Natural Environment}

In response to the question regarding whether they have noticed changes in the natural environment where they farm and in the weather during the past three years, almost $100 \%$ of respondents answered "yes".

When asked about the specific changes, respondents first identified "problems with rain" (between a third and two fifths of all respondents), followed by "heat-related problems" (about a quarter of the total responses), "problems with climate" and "problems with water" (see Figure 1).

When asked about the causes of the changes that they have noted in the natural environment of their work and the weather during the past three years, the study subjects noted "pollution" most often, with $26.2 \%$ of total responses. They referred to "global warming" second most often, and "climate change" as the third most reported cause. These three responses totaled almost $50 \%$ of responses. It is noteworthy that the references to "pollution" and "global warming" were significantly higher among contract workers than among landowners, and the references made in relation to "climate change" prevailed among the landowners (see Figure 2). 


\section{Changes noted in the environment ( $97 \%$ of respondents noted changes)}

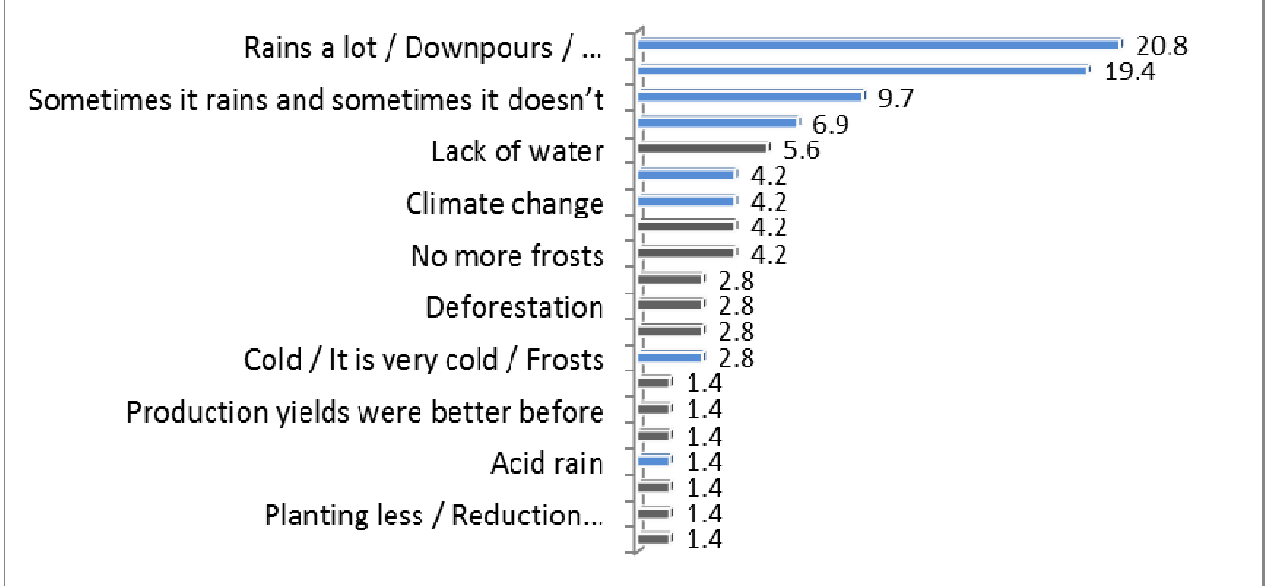

Figure 1. Changes in the environment.

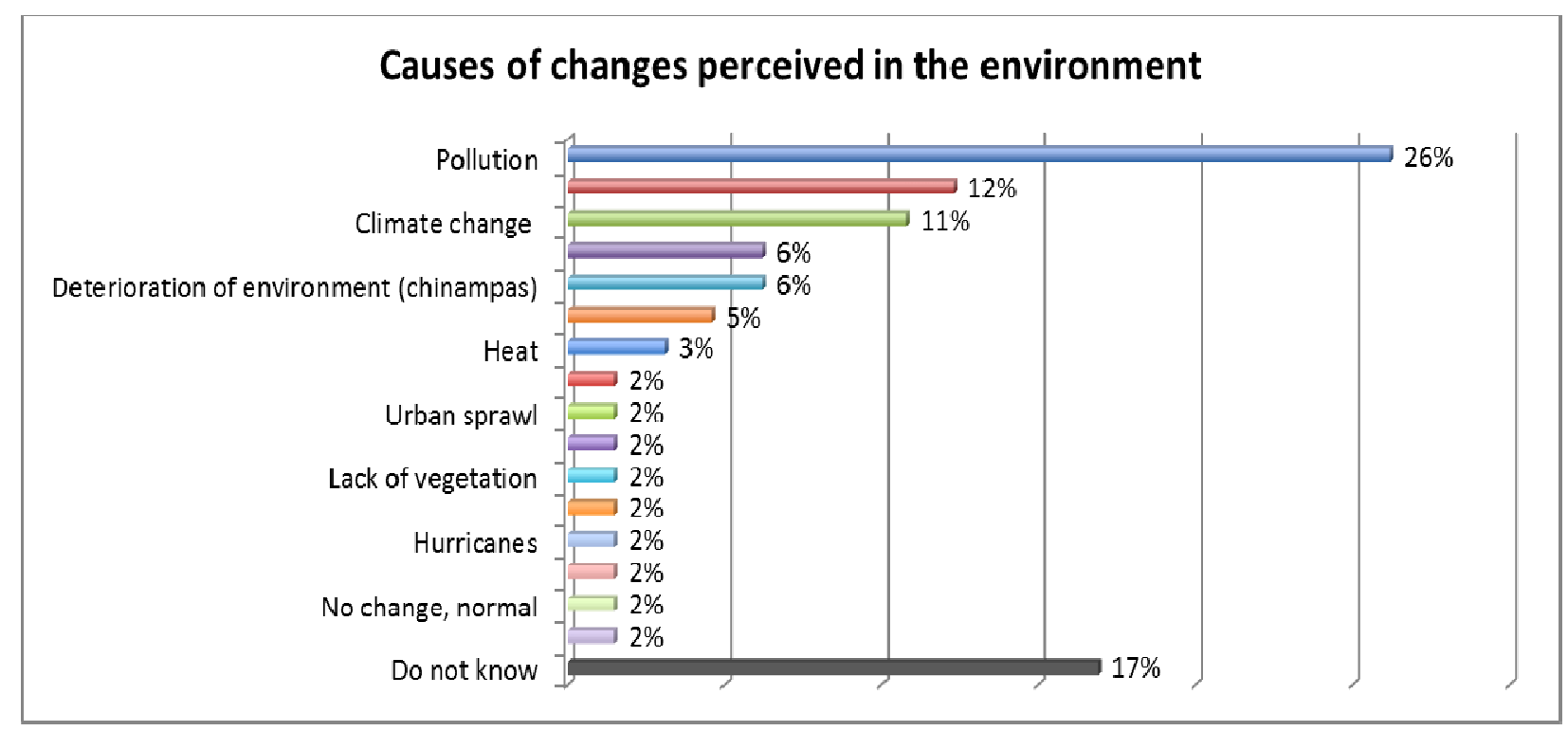

Figure 2. Perceived changes in the environment.

\section{Timely Perceptions of Changes in the Natural Environment}

With regard to the question comparing where they worked three years ago, more than half said that the vegetation had decreased. The landowners were much more likely to observe this decrease ( $72 \%$ of the total), while nearly a third of the hired workers thought that the vegetation had increased. Respondents listed reasons for the decline of vegetation as "pests" and "deforestation", followed by "change in weather/irregular climate" and "pollution". As reasons that have favored increased vegetation, respondents mentioned "better cultivation of planted seeds/ sown more", the increase in rain, and "crop rotation".

In relation to animals, just over half of the respondents expressed the opinion that the total number of animals have decreased compared to three years ago in the place where they work. Respondents listed the reasons as, first, that "people no longer keep livestock/no space", followed by "building of 
houses/invasion/urbanization". In third place, respondents pointed out that insects had increased because of increased rainfall and pests.

In regards to the water levels in the canals, more than three-fifths of respondents said that water levels had declined. Landowners and hired workers had the same response rate. When asked about the reasons for change in the water levels of the canals, the highest percentage of respondents attributed the cause to their dependence on the city of Xochimilco. Other causes that received a relevant number of responses by hired workers were cracks/leaks in the chinampas, as well as the fact that rising temperatures decrease the water levels, and lead to droughts. Meanwhile, the landowners reported climate change, collapsing chinampas, ground unevenness, tremors, the lack of water, the laying of pipes, and the exploitation of aquifers.

In regards to the changes identified in the environment over the course of three years, more than half of respondents agreed that the rains have increased. However, there were marked differences between the evaluation of this by landowners and hired workers While amongst the latter, $62.2 \%$ observed an increase in rains, only $42.9 \%$ of the landowners said the same, with only a third of the remaining sample mentioning a decline in rainfall.

When asked about the reasons for the change in rainfall, most said it was due to "climate change/changes in climate/weather". Following the same line of questioning, in response to the question of whether the drought had changed from three years ago, 56.8\% said that droughts had increased, registering broad agreement in both groups of farmers. It is notable that the cause most often cited was climate change, especially among landowners. The second most mentioned response referred to depletion of the ozone layer, a response made mostly by hired workers. The third most-cited cause was the sun/heat, only mentioned by hired workers. For landowners, in addition to climate change as the most-cited cause, the second and third most-cited causes were variables attributed to temporary conditions, such as drought, or with the laconic phrase "it is not like it was before".

With respect to frost, the views of the two groups were divided. However, both groups coincided in the prevailing view that the frosts had decreased (46.6\% of responses noting a decrease, and $35.6 \%$ of respondents noting an increase). Among the most common reasons for the causes of changes in the frosts and cold, respondents highlighted "climate change", "it is seasonal/temporary", and that the frosts are "less than before". However, at the same time, respondents cited that the cold is "more bitter" and more than a fifth of the total respondents and about a third of the hired workers responded that they did not know. When we asked about other changes not already mentioned that the chinamperos had observed in the natural environment where they work, both types of farmers mentioned "increased urban sprawl" first, followed by the repeated mention of "pollution" and the "increase of pests". In a third general reference level, they mentioned, "changes in the seasons". In a second mention, mainly landowners cited first and foremost, the "increased urban sprawl", followed by "pollution", "pests", and "temperature increase".

\section{Symbolic Imaginaries and the Mediation of "Climate Change"}

Three quarters of all interviewees said they knew the term "climate change" ( $83 \%$ for landowners and $71 \%$ of hired workers). Among these, nearly a third reported having heard the expression on "television", followed by the "news", and thirdly, on both "radio and television" (see Figure 3).

Almost $80 \%$ of the people surveyed associated "climate change" with the consequences of the phenomenon, highlighting sudden changes in temperature, changes in weather, increased temperatures, and 
changing seasons, among others. Although only about $8 \%$ of the farmers associated "climate change" with disasters, the percentage doubles amongst landowners (reaching $16 \%$ of responses). Only $4 \%$ of the landowners, indicated a relationship between "climate change" and human responsibility, and almost $11 \%$ of all respondents answered that they "do not know" how the two are related.

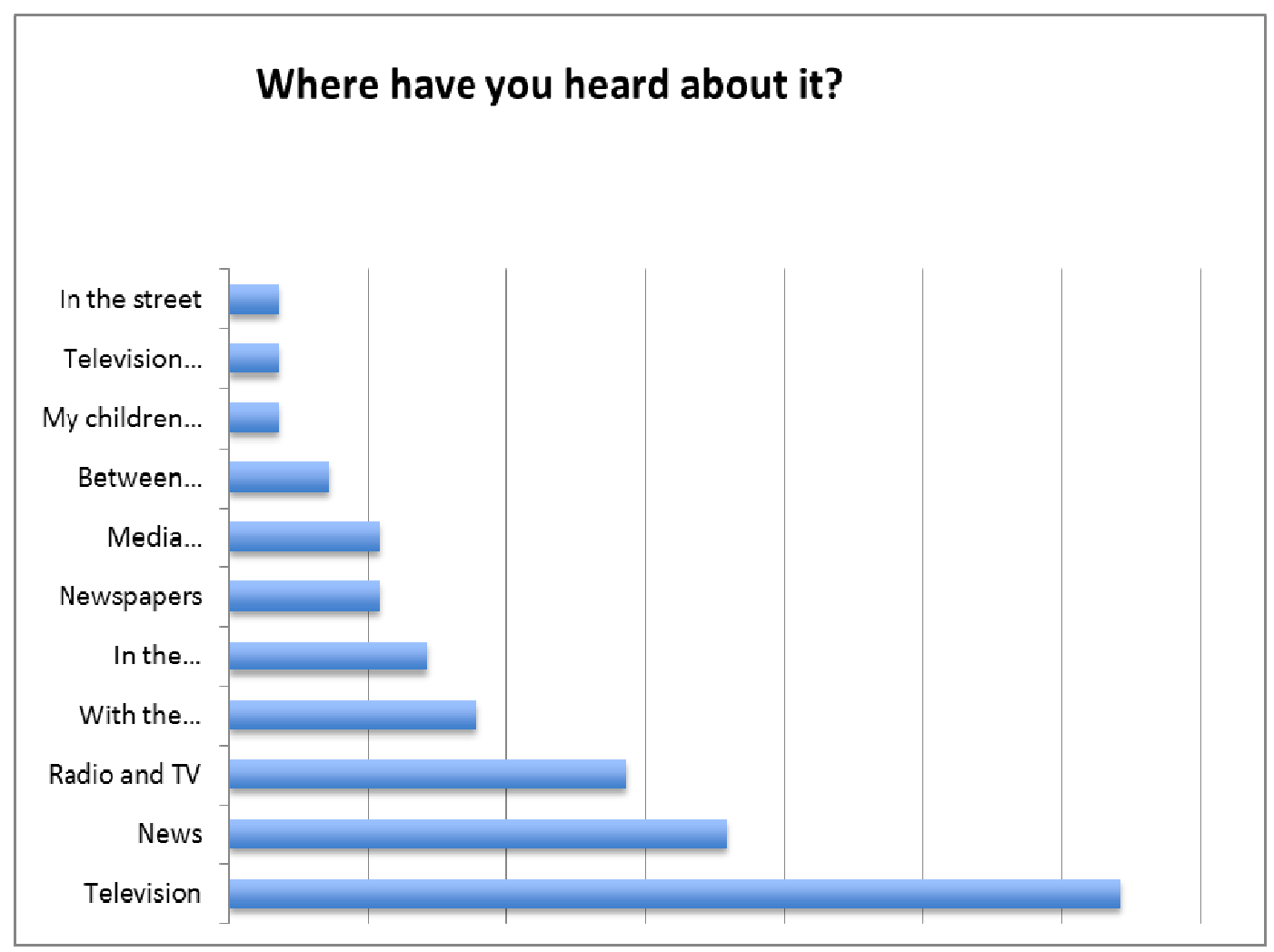

Figure 3. Mediation on climate change.

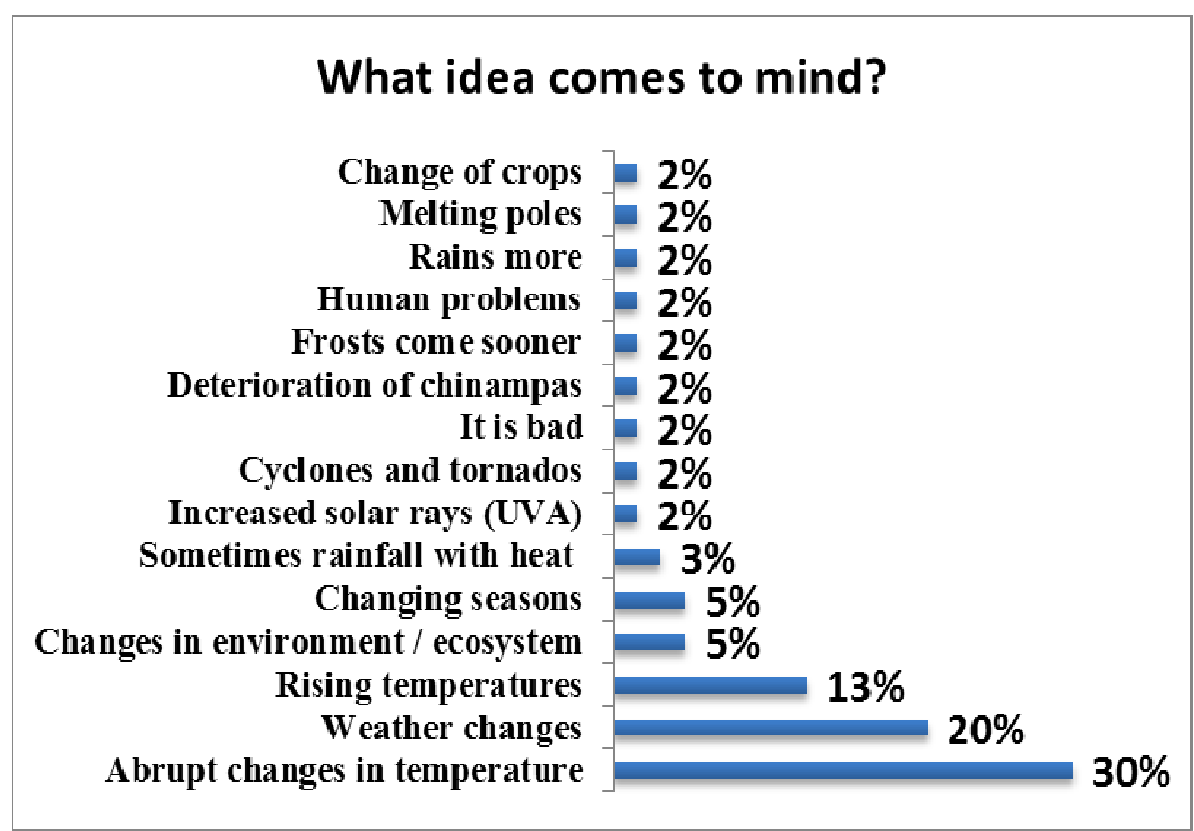

Figure 4. Relationship between the concept and everyday life. 


\section{Symbolic Imaginaries and Mediation of "Global Warming"}

In regards to the expression, "global warming", practically three-quarters of respondents said they were familiar with the term (about $90 \%$ of landowners and $64.4 \%$ of hired workers).

A quarter of respondents said that they had heard the term on "television", a fifth of respondents said that they heard the term on "the news", and a third of respondents said that they heard the term on the "radio and television" (see Figure 3).

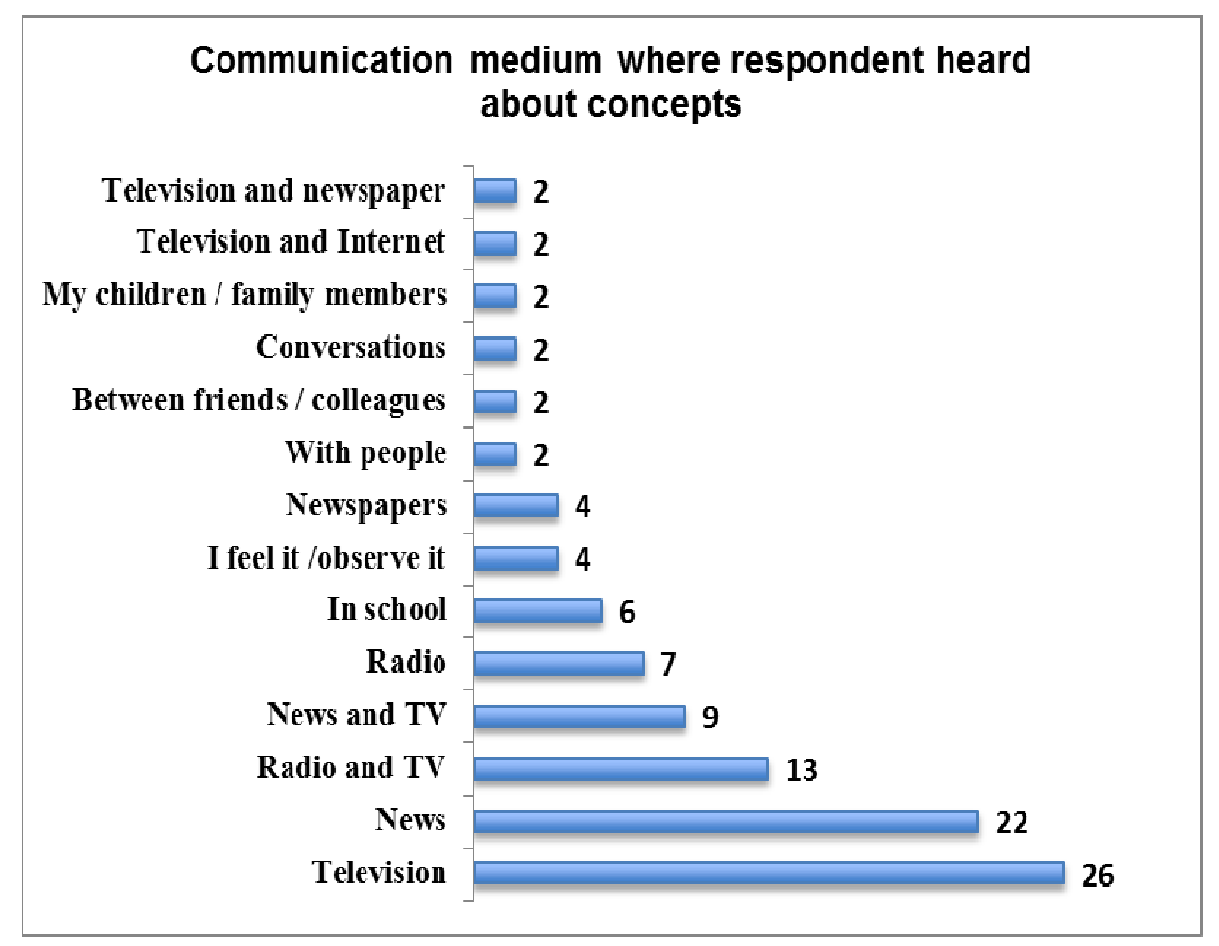

Figure 5. Mediations on global warming.

When asked what idea came to mind upon hearing the term "global warming", more than two fifths of the total sample (43.5\%) identified ideas associated with the consequences of the phenomenon, such as "increased temperatures on the planet", "climate change", "global warming and warming of the atmosphere", the "melting poles", and "total disruption of the ecosystem". In turn, $16 \%$ of respondents made associations with the causes of the phenomenon and, in third place, respondents made associations with issues related to human responsibility (14.5\% of the total). Finally, we should mention that about one fifth of the total respondents said they did not know. It should also be noted that a very small percentage of respondents associated global warming with natural disasters (see Figure 4).

The ideas that San Gregorio farmers receive from the media they consume is clearly expressed in the figure below, where we can see that television is the main mode in the construction of two dominant imaginaries "sudden changes in temperature" and "climate change", a trend followed by the radio, social networks and print news.

\section{Consumption of Mass Media}

Television is the mass media most consumed by respondents: nearly $93 \%$ identified television in the affirmative or the "more or less" categories. Slightly more hired workers than landowners cited television. Next, 
respondents identified the radio ( $85 \%$ in the same categories), with a higher response rate by hired workers than landowners. Print news comes in third with almost $62 \%$ of respondents. In this case, we saw the same frequency between hired workers and landowners in both variables, "yes" and "more or less". Finally, it is striking that in the case of social networks, the landowners answered more in the affirmative than hired workers, with higher frequencies in the variables "yes" and "more or less" (just over $41 \%$ compared to just over $36 \%$, respectively).

This cannot be taken as an example of the landowners' greater access and participation in social media, but rather as an example of increased marginalization in terms of Internet access and use within the subpopulation of contracted workers.

\section{Media Consumption and Perceptions of Accuracy}

The majority of respondents consider television to be the most accurate medium regarding information about "global warming" and "climate change". $62 \%$ of respondents consider television to be a clear and adequate information source about these phenomena, answering "well" or "more or less well" in response to the question. The second medium considered to be accurate and trustworthy is the radio with nearly $61 \%$ in these two variables ("well" and "more or less well"). Third, respondents indicated print news, and finally, social networks. The largest positive frequencies are concentrated from hired workers with the exception of radio and, paradoxically, social networks. A small group of people $(9.5 \%)$ mentioned alternatives, the most significant of them being the Bible. Hired workers also mentioned in very low frequencies other media such as school, books, observations, experience, etc.

\section{Discussion}

\section{Perceptions and Symbolic Imaginaries of Climate Change}

Most of the chinamperos of San Gregorio, Xochimilco perceive changes in the climate and the natural environment directly, highlighting increased rainfall, hail, showers, temperatures and drought. The fuzzy perceptions that respondents shared regarding observed changes in the environment mainly refer to pollution, global warming and climate change (see Figure 6).

In response to questions focused on timely perceptions, we found majority opinions regarding the reduction of vegetation (by pests and deforestation); decrease in the number of animals (livestock) due to urbanization and space reduction; increase of insects and pests; decreased water levels in the canals due to proximity to the city of Xochimilco; an increase in rainfall (contrasted opinion among subpopulations), or rather the observation of a serious randomization of traditional rainy seasons; increased drought attributed to climate change; decreased frost (though again, with opinions divided between subpopulations), also attributed to climate change; and finally, increasing urban sprawl, pollution and increased pests.

Symbolic imaginaries as derived from the semantic associations that chinamperos hold regarding the terms "climate change" and "global warming" are similar, but not identical. Regarding the climate change concept, the symbolic imaginary relates to the consequences of the phenomenon, highlighting the "sudden changes in temperature", the "climate changes", the "temperature gain", and the "change of seasons". Regarding "global warming", the symbolic imaginaries are also associated with the consequences of the phenomenon, highlighting the "increased temperatures on the planet", "climate change", "global warming and the atmosphere", the "melting poles" and "total disruption of the ecosystem", among the most important. 


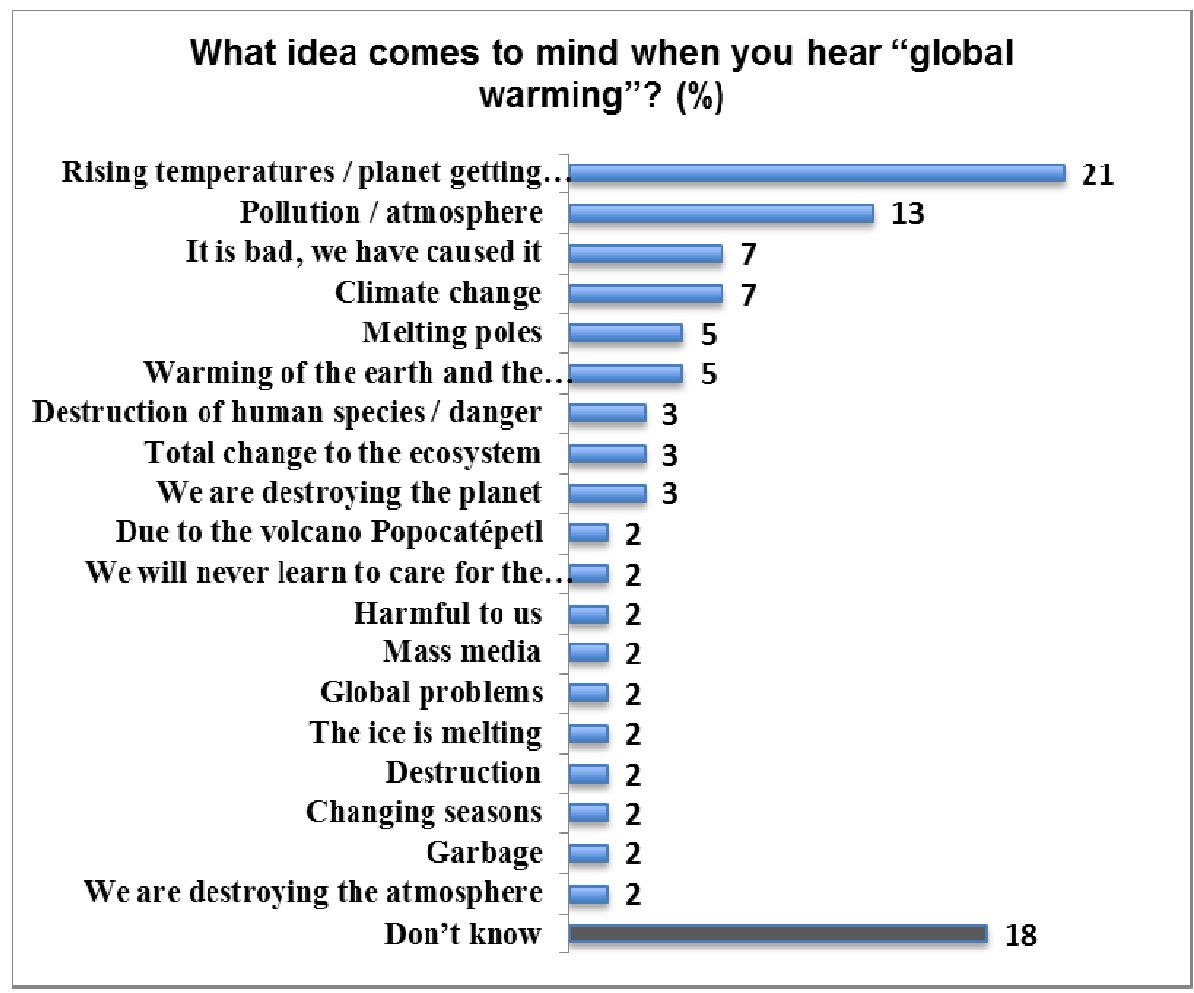

Figure 6. Relationship with everyday life concept.

The consequences of global warming are located in damages due to weather (40\%), disruption to plant and wildlife (almost one fifth of the total), and disruption to production. This last result becomes relevant once we considered a more concrete level of analysis, the effects on San Gregorio. The causes of climate change mentioned were, highlighting the most important: pollution, human activity as destructive of the environment, deforestation, trash and burning of trash, cars and the gases they produce, the use of chemical insecticides, among others. The study demonstrates a wide range of symbolic imaginaries that farmers hold in regards to the causes of climate change.

\section{Mass Media Consumption and Access to the Internet}

The most influential media in the semantic construction of these symbolic imaginaries are television, followed by radio, social media and the print news. Among the farmers interviewed, television is the dominant information source, followed by radio, social networks and print news. Furthermore, at the time of reporting, respondents identified television as the most trustworthy media source regarding "climate change" and "global warming" (see Figure 7).

Regarding the expressions of "global warming" and "climate change", practically three-quarters of respondents said they knew of the term via television as the dominant media source. More landowners than hired workers reported the television as dominant (see Figure 8).

Although reported to be least-used media source, landowners identified social networks to have a high level of veracity (an opinion not shared by hired workers) (see Figure 9).

Just under two thirds of the agricultural population uses a cell phone, with slightly more hired workers than landowners reporting cell phone use. Of those using a cell phone, the vast majority (87\%) uses it viapre-payment plans. Amongst the small sector that have Internet only, less than a quarter use it. 


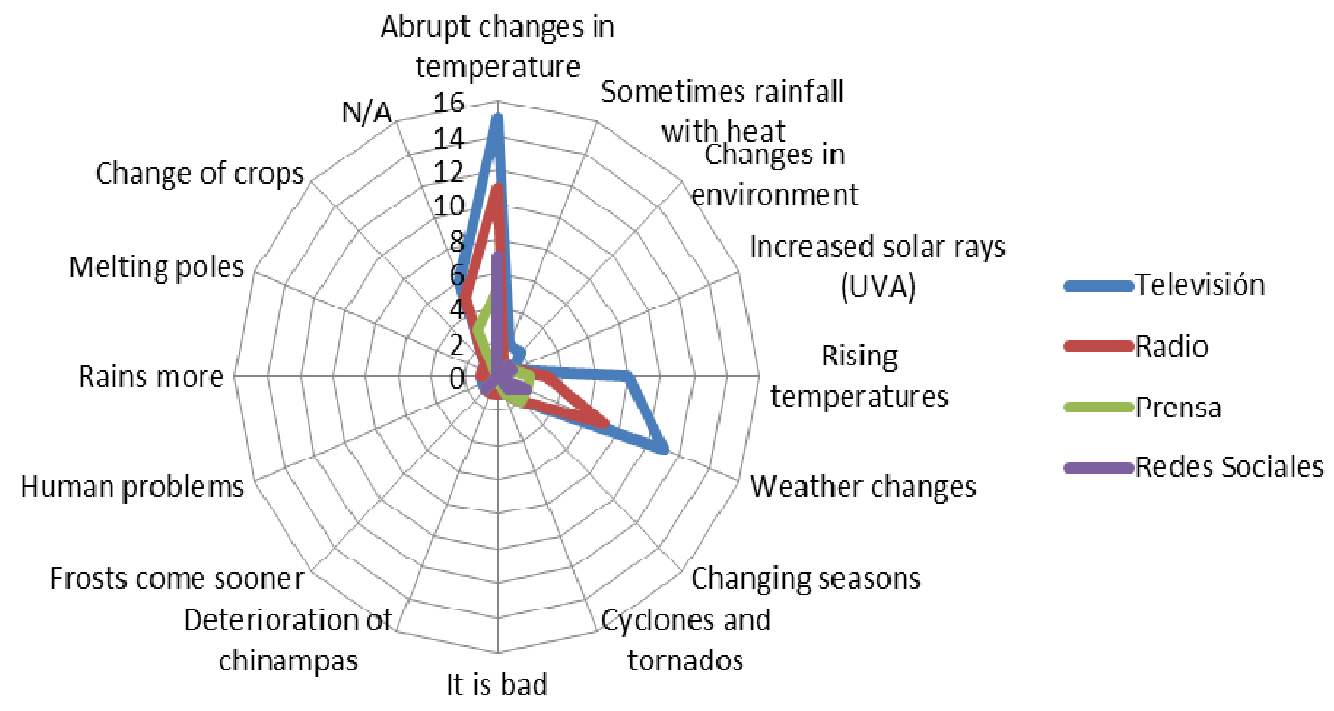

Figure 7. Television, dominate media.

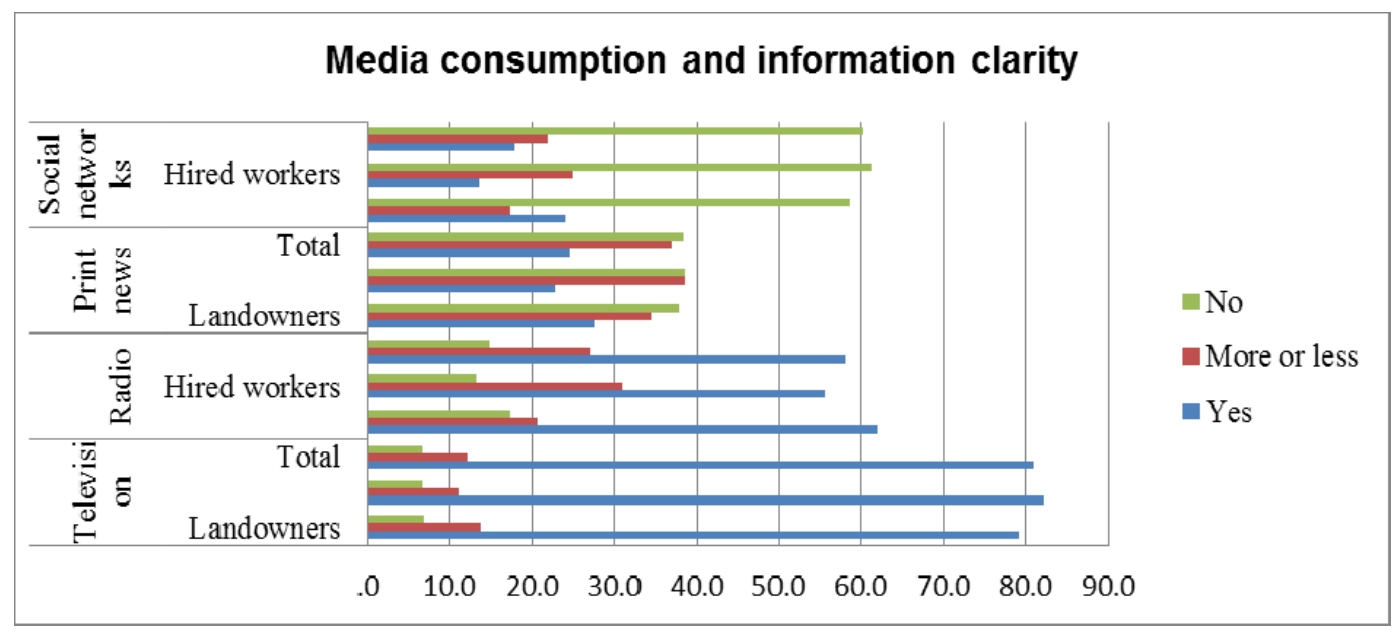

Figure 8. Media consumption.

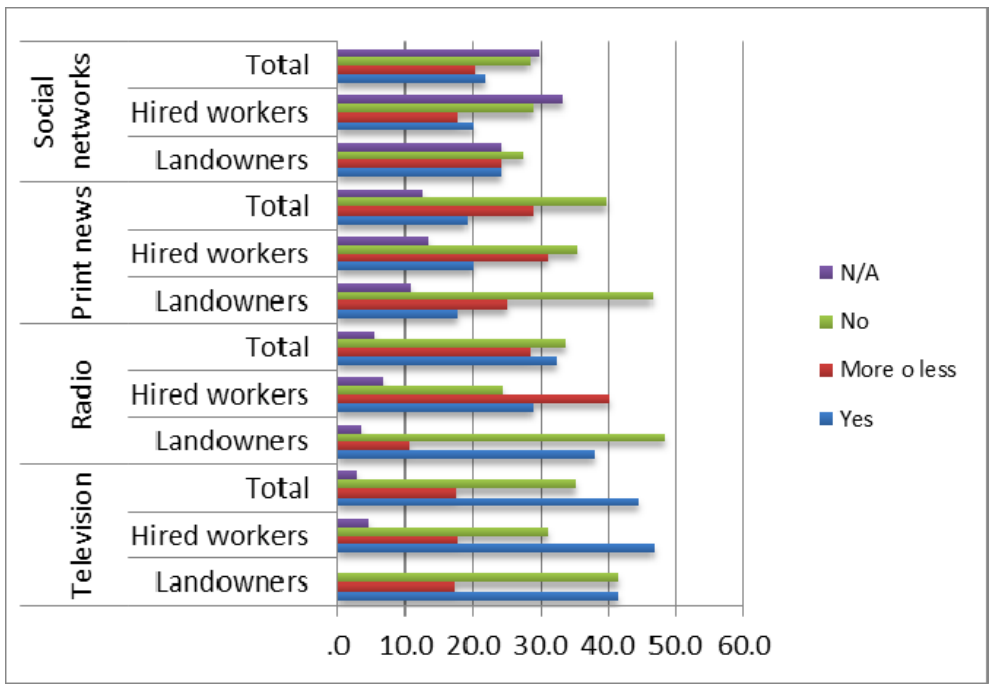

Figure 9. Media and clarity of the information. 
$73 \%$ of the population reports having no Internet service. And amongst those who do have access, they report a similar percentage via cell phones and computers. Hired workers report use of the Internet via their cell phones, although only $18.2 \%$ use it. Thus, we observed a huge gap in Internet access, where in close to $80 \%$ of the total population does not have or do not use Internet access.

A notable minority, formed exclusively by hired workers, report knowledge of the emergency services provided over the Internet, a logical consequence of the lack of access. The mechanisms by which the population chinampera of San Gregorio learns about local emergencies are mainly via word of mouth or by people's stories. In this sense, it is clear that there is no internal source of information about what is happening in San Gregorio other than that of the traditional neighborhood.

More than half of the population thinks there is a possibility of risk of or the occurrence of a catastrophe in San Gregorio. Most opinions located these risks in four possible events: flooding, sinking of chinampas, construction on muddy soil, and cracks or the opening of cracks as a result of earthquakes. Most of those interviewed considered useful or very useful the implementation of a computer application to support the agriculture community in San Gregorio.

The fuzzy perception of changes in their environment coincides with media perceptions. The results show a direct relationship between television consumption and dominant symbolic imaginaries associated with "climate change" and "global warming". That is, mediation creates dominant symbolic imaginaries associated with the increase in temperature, climate change, drought, decline in wildlife, and low agricultural production. However, human mediation, i.e., friends and family members, are shown to be as important as television and the Internet in the perception of and information around "climate change" and "global warming".

\section{Conclusions}

From this study, we can begin to question the relevance of the terms "climate change" and "global warming" when exploring the problems and solutions facing the community of chinamperos in San Gregorio in regards to the changes in their natural environment throughout its history and in to the present.

We identified problems in the use of language when members of the community communicated about the issues related to weather variation, the natural environment, and the environment in which they lived and worked. The terms "climate change" and "global warming" are not functional once the chinamperos began to describe the problems they experience, the effects, and the possible solutions in the face of climatic changes. Despite the identification of symbolic imaginaries viafuzzy and timely perceptions as perceived through information consumed on television, radio, social networks and print news, and as shared with other members of the community, the terms "climate change" and "global warming" appear to evolve more from a mediation of terms than from the local and personal experience expressed in other words.

It is essential to explore the language used by the farming community when thinking, proposing and articulating mediation discourses, public policies, civil society actions, and scientific research as related to weather variations in local environments affected by climate change, as in the case of San Gregorio.

Furthermore, this study reveals a major digital divide in Internet access between the agricultural community of San Gregorio and the urban inhabitants in Mexico City. However, a positive assessment on the use of Internet as an information source is identified. The population is open to Internet use despite experiencing access difficulties. 
The results provide insight into the media as well as the language that the population uses to construct meaning and action around climate issues and changes in San Gregorio. These results may be useful to identify areas of opportunity for community development, prevention, information and joint actions for resilience between the community, civil society, local government, non-profit organizations, private companies, as well as, educational and research institutions.

\section{References}

Aliaga, F., Basurto, O., \& Cabrera, J. (2013). El grupo de discusión: Elementos para la investigación en torno a los imaginarios sociales (The discussion group: Elements for research on the social imaginary). Retrieved from http://www.isdfundacion.org/publicaciones/revista/numeros/9/secciones/tematica/06-grupo-discusion.html

Appadurai, A. (2001). La modernidad desbordada: Dimensiones culturales de la globalización (The unbridled modernity: Cultural dimensions of globalization). Argentina: Fondo de Cultura Económica.

Baeza, M. A. (2002). De las metodologías cualitativas en investigación científico social: Diseño y uso de instrumentos en la producción de sentido (Of qualitative social scientific research methodologies: Design and use of instruments in the production of meaning). Concepción: Ed. Universidad de Concepción.

Barbero, J. (2003). De los medios a las mediaciones (From media to mediations). Bogotá: Convenio Andrés Bello.

Carretero, E. (2009). Imaginario y violencia intracomunitaria: La racionalidad politica y las formas anómicas de presentación de la violencia en las sociedades postmodernas (Imaginary and intra-community violence: Political rationality and anomic forms of presentation of violence in postmodern societies). Retrieved from http://dialnet.unirioja.es/servlet/articulo?codigo=3411500

Castoriadis, C. (1983). La institución imaginaria de la sociedad (The imaginary institution of society). Barcelona: Tusquets.

Castoriadis, C. (1984). Imaginarios: Desarrollo y aplicaciones de un concepto crecientemente utilizado en las Ciencias Sociales (Imaginarios: Development and application of a concept increasingly used in the social sciences). Retrieved from https://www.wzb.eu/www2000/zkd/dsl/pdf/Rovira/imaginarios.pdf

DRAE (Diccionario de la Real Academia Española). (2015). Artículo en líneadisponible en. Retrieved from http://lema.rae.es/drae/?val=chinampa

Garcia, F. (2009). Construcción del discurso social (Construction of social discourse). Retrieved from $\mathrm{http} / /$ www.isdfundacion.org/publicaciones/revista/numeros/2/editorial.html/

García, F., \& Millán, M. (2008). Lapercepción de lo social: análisis de los mensajes sociales (Perception of the social: analysis of social messages). Retrieved from http://www.isdfundacion.org/publicaciones/revista/pdf/8.pdf/

Garcia, N. (2006). El consumo cultural: una propuesta teórica", El consumo cultural en América latina. Construcción teórica y lineas de investigación (The cultural consumption: A theoretical proposal. Cultural consumption in Latin America. construction and theoretical research). Bogotá: Convenio Andrés Bello.

Glynn, C. J., Herbst, S., O'Keefe, G. J., \& Shapiro, R. Y. (1999). The history of public opinion. Retrieved from $\mathrm{http}: / /$ www.ipcc.ch/publications_and_data/publications_and_data_glossary.shtml

INEGI. (2010). Censo Nacional de Vivienda del Instituto Nacional de Estadistica y Geografia (National Housing Census National Institute of Statistics and Geography). INEGI: México.

IPCC. (2002). Cambio climático y biodiversidad. Grupo intergubernamental de expertos sobre el cambio climático (Climate change and biodiversity: Intergovernmental Panel on climate change). Retrieved form https://www.ipcc.ch/pdf/technical-papers/climate-changes-biodiversity-sp.pdf

Leff, E. (2010). Imaginarios sociales y sustentabilidad (Imaginarios and social sustainability). Retrieved from http://www.revistas.unam.mx/index.php/crs/article/view/19202

Levy, D. L., \& Spicer, A. (2013). Contested imaginaries and the cultural political economy of climate change. Organization, 20(5), 659-678.

Luke, T. W. (2014). The climate change imaginary. Retrieved from http://csi.sagepub.com/content/early/2014/12/19/0011392114556593

Moreno, B., \& Rovira, C. (2009). Imaginarios: Desarrollo y aplicaciones de un concepto crecientemente utilizado en las Ciencias Sociales, Programa de las Naciones Unidad para el Desarrollo Dirección Regional para América Latina y el Caribe (Imaginary: Development and application of a concept increasingly used in the social sciences, Nations Programme Development Unit Regional Bureau for Latin America and the Caribbean). Retrieved from https://www.wzb.eu/www2000/zkd/dsl/pdf/Rovira/imaginarios.pdf 
Murillo, S., \& Mena, L. (2006). Detectives y camaleones: el grupo de discusión. Una propuesta para la investigación cualitativa (Detectives and chameleons: The discussion group. A proposal for qualitative research). Madrid: Ed. Talasa.

Norlatina. (2014). Encuesta sobre Percepción del cambio climático de los agricultores chinamperos de San Gregorio Atlapulco, Xochimlco (Survey on perception of climate change farmers of San Gregorio Atlapulco, Xochimlco). Mexico: Norlatina.

Oskamp, S., \& Shulz, W. (1991). Attitudes and opinion. New York: Psychology Press.

Pintos, J. (1995). Los imaginarios Sociales: La nueva construcción de la realidad social (Social imaginary: The new construction of social reality). Cantabria, Madrid: Sal Terrae.

Pintos, J. (2004). Inclusión-Exclusión. Los imaginarios sociales de un proceso de construcción social (Inclusion-Exclusion: The social imaginary of a process of social construction). SEMATA. Ciencias Sociales y Humanidades, 16, 17-52.

Plaza, D. (2009). La construcción discursiva de la nación a través del fútbol. Un discurso social de éxtio. El fenómeno Eurocopa 2008 en España. (The discursive nation building through football. Extio social discourse. The Euro 2008 phenomenon in Spain). Retrieved from http://www.isdfundacion.org/publicaciones/revista/numeros/2/tematica/01-construccion-nacion.html/

SEMARNAT. (2009). Cambio climático: Ciencia, evidencia y acciones (Climate change: Science, evidence and actions). Retrieved

from http://www.semarnat.gob.mx/archivosanteriores/informacionambiental/Documents/05_serie/cambio_climatico.pdf
UNESCO.
(2015).
Glosario
(Glossary).
Retrieved
from http://www.unesco.org/es/education-for-sustainable-development/esd-e-module/toolkit/glossary/

Yusoff, K., \& Gabrys, J. (2011). Climate change and the imagination. Wiley Interdisciplinary Reviews: Climate Change, 2(4), 516-534. 